\title{
PROSPECTS OF ASEAN LEGAL COOPERATION
}

\author{
Agus Riyanto \\ Department of Business Law, Faculty of Humaniora, Bina Nusantara University \\ Jl. Kemanggisan Ilir III No. 45 Palmerah, Jakarta 11480 \\ agusriyanto@msn.com
}

\begin{abstract}
Association of Southeast Asian Nations (ASEAN) is a regional organization in the countries of Southeast Asia established in Bangkok, Thailand, on August 8, 1967 (the Bangkok Declaration) by Indonesia, Malaysia, Philippines, Singapore, and Thailand. One form of cooperation that could further encourage the establishment of ASEAN's goal was legal cooperation. This was because, this cooperation could further strengthen cooperation in politics, economy, social and culture in Southeast Asia. This paper aimed to identify and learn how the real prospect of legal cooperation could be realized. Therefore, it should be known that areas of cooperation of the law which allows conducted cooperation among ASEAN countries use sectoral laws as an alternative legal cooperation. Method of this paper was comparative law in the ASEAN countries due to the countries in Southeast Asia have different legal systems. The result of this paper is the prospects of ASEAN legal cooperation is very open to be realized, because the settings are clear legal basis exists and regulated. Just to get to the realization of such cooperation, the ASEAN countries must have a strong political will to become solid cooperation.
\end{abstract}

Keywords: prospects, legal cooperation, sectoral laws

\section{INTRODUCTION}

ASEAN is the only association of the countries in Southeast Asia that has proved itself institutionalized solidly and can survive until now, since ASEAN really has a solid foundation in implementing cooperation. ASEAN continues to grow, proceed, and develop for more than 47 years. Gradually, the differences in national interests, economics, and the law of the countries that comes from inequality historical background experienced by these countries in the past are diminishing, because of the mutual regional interests to cooperate. One of the cooperation in ASEAN that urged to be realized is the law cooperation, although it must be admitted that this cooperation is not simple. Regional legal cooperation of ASEAN is condition sine qua non to accomplish the unity of its countries.

Embodiment of ASEAN legal cooperation is little bit difficult because the difference in the system of government. However, the strong passion and political will of ASEAN countries can be suppressed these difficulties. Another obstacle that faced by ASEAN countries in implementing this cooperation is differences in legal systems. Indonesia embraces legal system of Continental Europe, whereas Brunei Darussalam, Singapore, and Malaysia embrace legal system of Anglo-Saxon, and Thailand and Philippines are collaboration between the legal system of Continental European and Anglo Saxon. Meanwhile, Vietnam, Laos, Myanmar, and Cambodia embrace the legal systems that are closer to the legal system in China. All of these differences make the implementing of the cooperation are getting difficult. 
If the cooperation in legal system cannot be done because of its pluralism, then the other ASEAN regional cooperation such as, political, economic, social, and cultural most likely will face obstacles. The regional cooperation in political, economic, social, and cultural will not be able to thrive, develop, and constructive in the future, because the legal aspect is the root of problem. The cooperation of legal system can be the bridge to reach goal of ASEAN regional cooperation that proposed in the Bangkok Declaration (1967).

For this reason, there is a fundamental question that must be answered about the areas of legal cooperation, such as what cooperation that will be agreed upon by the ASEAN countries, and then formulated into principle guidance in solving problems together. The answer to these areas will be able to answer how exactly the prospects of cooperation of ASEAN law is implemented in the middle of the diversity of legal systems prevailing among the ASEAN countries.

\section{METHODS}

Method of this research is comparative law in the ASEAN countries due to the countries in Southeast Asia have different legal systems. The different of legal systems of these countries are not compared as a whole and depth, but it shows general overview and basic principles and then tries to look for the equal point of the legal system among these countries. Through that equal point, the prospect of ASEAN legal cooperation in the future will be realized. This method is a jointly effort of ASEAN countries to do cooperation because the different legal system among these countries are not easily united. However, it does not mean that the ASEAN countries cannot cooperate in the field of law. ASEAN countries can still cooperate with passion and togetherness that have been running for decades.

\section{RESULTS AND DISCUSSIONS}

Since the establishment of ASEAN, 47 years ago, the desire to conduct cooperation in the field of law has existed. The desire was not directly stated, but based on the verse 2 of the goal and purpose of the Bangkok Declaration (1967), the desire has already existed and was formed as follows:

"To promote regional peace and stability through abinding respect for justice and the rule of law in the relationship among countries of the region and adherence to the principles of the United Nations Charter"

Based on that statement, it appears that since the beginning of the founders and a drafter of the ASEAN, it has realized the importance of legal cooperation between each other. Through shared determination, making legal cooperation of ASEAN is a need. However, the field of legal cooperation has not been formulated among ASEAN countries. Actually, the legal cooperation had already existed, but the cooperation was still the general one.

After 20 years of Bangkok Declaration (1967), a milestone of ASEAN legal cooperation received confirmation through the Declaration of ASEAN Concord in 1976, particularly the program A, political section grains $6^{\text {th }}$ that stated:

"Study on how to develop judicial cooperation including the possibility of an ASEAN Extradition treaty" 
Based on the ASEAN declaration, it can be seen that desire to cooperate in the ASEAN countries has become clear. For the first time the cooperation explicitly stated as judicial cooperation between ASEAN member states. ASEAN countries can make this declaration as juridical basis to establish legal cooperation in realization. It because of firmness is needed to make it as a source of direction in the stretch and realizing the legal cooperation in intra-ASEAN relations in the future. Bangkok Declaration and the Declaration of ASEAN Concord is an inseparable link with each other. These two declarations are mutually support and complement each other in creating a legal framework for cooperation in the ASEAN countries.

After these declarations, ASEAN Task Force held in Kuala Lumpur on February $10^{\text {th }}, 1983$. This assembly discussed about legal cooperation authorized by the ASEAN countries for the first time. For this purpose, the Secretary General of the ASEAN Law Association was invited to express his thoughts about the subject of ASEAN legal cooperation. Through a working paper entitled Some Thoughts on Legal Cooperation among ASEAN Countries, the Secretary General of the ALA suggests the importance of legal cooperation regionally. He proposed some ideas and steps that can be taken to strengthen and implement effective cooperation in the field of law among ASEAN countries. Then, it is proposed that for the present stage of development, legal cooperation ASEAN countries may include cooperation in the establishment of regional legislation, cooperation in judicial and law enforcement, cooperation in law enforcement and law research, and cooperation in exchange the matter of law. (Hartono, 1983).

Results of the trial ASEAN Task Force then disseminated and discussed again in ASEAN Standing Committee in Bangkok, Thailand, on June $23^{\text {rd }}$, 1983. After through a discussion based on the ASEAN Task Force trial results, then consideration and recommendation from the Secretary General of ALA, finally the trial decided: (a) To accept in principles the proposal to initiate cooperation in the legal field, (b) To welcome the roles and contributions of the ASEAN Law Association in the formulation of programs of legal cooperation among member countries, (c) To request the ASEAN Law Association to initiate wherever possible such programs of cooperation and in their own right to submit the proposal to appropriate ASEAN machinery. (Radhie, 1983).

ASEAN Standing Committee's decision is a sign of progress in legal cooperation, because through the meeting also agreed on common principles to narrow the differences that exist so far between the ASEAN countries. Two years later, in the $7^{\text {th }}$ meeting of ASEAN Standing Committee on March $24^{\text {th }}$, 1985 in Kuala Lumpur, a delegation from Indonesia submitted a proposal on the establishment of a sort of forum for communication between the Minister of Justice and Attorney General in all of ASEAN countries to cooperate in the field of law. After experiencing several delays, the proposal was finally accepted by the ASEAN.

Furthermore, at the same meeting, the idea of Indonesia delegation was agreed and can be done immediately. But before doing it, a meeting of high officials of law from each ASEAN country to talk about things needed to be discussed later must held. To carry out the mandate of the $7^{\text {th }} A S E A N$ Standing Committee, then on September $25^{\text {th }}$ until $28^{\text {th }}, 1985$, in Jakarta was held ASEAN Cooperation In Legal Field Legal Senior Officials Meeting (ASLOM) which was attended by high officials of the law-state government representatives of ASEAN countries for the first time.

This meeting concluded that it was necessary to hold a meeting of the Minister of Justice and Attorney General of ASEAN to hold consultation on legal cooperation plan that will be implemented. Thus, the delegation will immediately convey these conclusions to each administration to get approval as soon as possible. Meanwhile, after hearing proposals from the Indonesian side in the paper Specific Issues of Legal Cooperation, the meeting finally agreed with the proposal as a court decision, which stated that legal cooperation will consist of cooperation in the field of justice, education, legal research, and exchange of legal materials. Finally, the governments of ASEAN countries agreed upon the deployment of the Minister of Justice and Attorney General to the Ministerial Meeting held on 
April $11^{\text {th }}$ to $12^{\text {th }}$, 1986 , in Denpasar Bali, Indonesia to discuss the possibility of legal cooperation in ASEAN. (Nugroho, 1986).

At that time, the meeting attended by five Justice Ministers, three Attorney Generals, and a Law Minister, as well as the representative each delegation. It is a concrete step in the effort to explore the wider legal cooperation in ASEAN countries. The last results of that two days meeting then outlined in ASEAN Ministerial Understanding on the Organizational Arrangement for Cooperation in the Legal Field as a joint legal agreement. The agreement included: (1) That legal cooperation among ASEAN Countries shall initially comprise the following three aspects; exchange of legal materials, judicial cooperation and legal research, legal education and legal research, (2) That be three aspects of legal cooperation shall be studied further by senior or more experts in as the may deem necessary, (3)That the ministerial of Justice, Ministers of Law and Attorneys General shall meet at such intervals as may be deemed appropriate and necessary in order to, inter alia, review the work of the Senior Legal Officials and give directions as may be appropriate thereto.

The first meeting of the Justice Ministers and Attorney Generals of ASEAN is a new chapter in the development of ASEAN legal cooperation. Through this meeting, each government of ASEAN countries held a collaboration to bridge the different of legal systems among them formally and consciously. In addition, because the agreement will continuously revised, so the Justice Ministers and Attorney Generals of ASEAN countries had established a forum, which can be used to consult each other, shared information on legal developments in each countries respectively, and talk about common interest in the field of law or legal issues of ASEAN countries.

Looking back to the purpose of meeting, it seems that the establishment of consultation forum between Justice Ministers and Attorney Generals would not be too difficult and would not take much time to discuss. It because of the forming of concrete rules that used as a regional legal principle is not too protruding. The effectiveness of the consultation forum in solving existed problem is highly depends on the smooth running of diplomacy and negotiation in order to implement its law. The major national interests of the countries that have problems could make it more difficult to run course of diplomacy and negotiation talks over the issue of the legal cooperation.

As recent developments, in summit of ASEAN III in Manila, Philippines, on December $14^{\text {th }}$ until $15^{\text {th }} 1987$, is a series of efforts to strengthen legal cooperation between ASEAN countries. It is becoming increasingly legal recognition from the government of ASEAN countries. That recognition can be seen from the final results of the meeting in Manila Declaration 1987, particularly in the section of Functional Cooperation $19^{\text {th }}$ dictum as following:

"ASEAN shall intensify its cooperation on health drug abuse prevention and combating illicit trafficking in drug, labor, law, population, child, survival and welfare, socio cultural programs and science and technology"

The declaration above is the actual concepts and ideas in realizing of joint agreement among ASEAN countries. However, the concepts and ideas towards a concrete legal cooperation still take more time to require adjustments in other areas at the national level ASEAN. So, countries need to be reassured that their national interests are not likely to be harmed by the regional legal cooperation, as concern over the years.

It is not all fields of law are suitable to unite in legal cooperation. International economic law is good choice to do cooperation between ASEAN countries because it has the same rules, so that it will make easier process in trading among the country members (David, 1990). The examples of international economics law are law of carriage, international trade law, and copyright patent. These fields are good to cooperate, because the rules are same in every country. So, if the cooperation in these fields happened, it will make the trade process between them easier. Generally, these areas are 
referred as Sectoral Laws. For the fields of law, such as: Family Law, Marriage Law, Inheritance Law, Agrarian Law and Divorce Law are too difficult to be harmonized, because these fields are very closely related to cultural background, religion and the emotional life of a nation. So it is difficult to cooperate even relatively in certain area. These fields are referred as the Basic Law.

Thus, the biggest possibility to do cooperation is in Sectoral Laws, because it can be developed and harmonized. While Basic Laws are too difficult to cooperate, because of differences in legal systems, history and cultural bridge between countries ASEAN looks too obvious. Therefore, priority in legal cooperation among ASEAN countries should be directed to the International Trade law, such as Banking Law, Contract Law, Corporate law, Insurance Law, Transportation law, etc. It because of these fields do not directly touch the cultural and national legal awareness of each country. Despite of different national legal systems, the difference is not an obstacle to create legal rules that the agreement material is more neutral.

To carry out the intention of the legal cooperation, the role of Model Law concept on ASEAN legal cooperation is huge to find a rapprochement the different legal systems among ASEAN countries. Now, the problem is who will design and create the concept of Model Law that will be agreed jointly. Otherwise, if the ASEAN countries accept the formulation of legal cooperation, it must be accepted with the consequences that the content of old law in each country should be changed in accordance with the Model Law that has been designed jointly. It is considering that ASEAN is not a supranational regional organization in relation to each other that can impose its will.

Teuku Mohammad Radhie (1987) said that most appropriate for designing and creating the concept of Model Law is the ASEAN Secretariat as joint representatives of ASEAN countries. Then, the result of design and creation through the ASEAN Standing Committee was confirmed in a meeting forum of the ASEAN Foreign Ministers or through the forum for the Justice Minister and Attorney General of ASEAN institutionalized obtains approval. However, the final design of Model Law has obtained the green light from the government of the ASEAN countries. But, there is still the possibility of several ASEAN countries who do not want to emulate and take over the formulation of Model Law that had been prepared jointly, specifically rejected its concept, because legally it is not binding.

Certain ASEAN countries refuse to modify their national law to the concept of Model Law and it proves that there is no legal harmonization about the agreement between ASEAN countries. Conversely, if ASEAN countries accept the formulation of legal cooperation, the principles contained in the formulation of the Model Law must be accepted with consequences that the rules of the old law of the country should be changed in accordance with the Model law. The advantage of legal cooperation through this Model Law is free to receive and make the formulation according to national law. However, it is the largest program encountered in the legal harmonization through the concept of Model Law. For one reason or another, specific countries will receive or aside this Model Law, if the perceived conflict with national interests.

\section{The Prospect of ASEAN Legal Cooperation}

The different opinion among ASEAN countries about this cooperation raises the question of how legal cooperation can be realized and what are the prospects of the ASEAN legal cooperation in the future. However, when viewing interests and common goals to be achieved among ASEAN countries, there is a reasonable expectation to arrange the law, so that all of ASEAN countries will use the same law regulation in the future. It emphasizes that the ASEAN legal cooperation is only possible in the area of Sectoral Laws, while in the area of Basic Law, it is little bit difficult and impossible. The legal cooperation in specific regional areas, including ASEAN, in addition to strengthen the goal to establish of a regional organization, in general there is more than one purpose in establishing legal cooperation, includes: 1) To strengthen political ties between the two countries or more, 2) To reflect 
the cultural similarities between some countries, 3) To create a legal system, particularly in the legal relations that are regional and international.

Legal cooperation is important to ASEAN countries, especially to obtain a legal basis in the ASEAN regional. It is not only important in order to expedite the legal relationships between the ASEAN countries themselves, but also to facilitate relations between ASEAN countries with dialogue partners as well as other countries, such as USA, Japan, the European Economic Community (EEC), Australia and New Zealand.

The literature study showed that legal cooperation can be done, including in this case between the ASEAN countries, it will reach two things: a) The rules of law are harmonized. Does the harmonized were confined to the civil legal norms or international economic or preferably on legal norms material (substantive law) that governs something harmonized. Regarding the last case needs to be examined again whether one of the country material law can already be considered to adjust itself with other legal systems. On the other hand, is it necessary to create a set of new material legal norms to regulate the relations between between ASEAN countries themselves, which can later be used as the basis for realizing the ASEAN legal cooperation. b) Means to hold legal harmonization. This issue concerns the matter of means to harmonize the law. Is harmonization of law in a particular area that is more easily cultivated through international agreements, through legislation, a court ruling (jurisprudence) and arbitration, or through international contracts that ultimately will create a legal contract applicable to ASEAN.

In the $20^{\text {th }}$ century, according to the understanding of state sovereignty and the rule of law of each country is not possible to hold the harmonization of material law rules (substantive law). Then, the collaborative efforts of law in the $20^{\text {th }}$ century is more harmonize concerning Civil Law or International Economics, the rules of jurisdiction and authority issues the judge in resolving the dispute. Unfortunately, experience has shown that in legal cooperation in the field of Civil Law or International Economic are not easy to setup the event or international relationship. Therefore, it is not easy to formulate that collective agreement.

Thus, the legal cooperation in this new phase intends to: 1) Determine which the national legal system would apply to legal events that contains international elements, 2) Determine which the state judge who is authorized to make decision in the case or international case, 3) To ensure that the documents used in international relations remain valid in other countries, including the national court ruling that required by international agreements on that legal cooperation.

In cooperation, substantive legal rules for ASEAN countries do not always have to be formulated the new law. However, there is the possibility of legal norms that have been prevailing in one of the ASEAN countries can also be applied to all ASEAN countries. This path may be faster than formulate the new law. Previously had done a study, research, and mastery of a truly profound about the area of the law to be applied. Because the views and conclusions of the all general (general studies) only is not sufficient. In general, when talking about legal cooperation, usually people immediately recall the international multilateral agreements between more than two countries. However, there are still lines or other means through the cooperative efforts of the law can do. That path such as through a court decision, decision of the arbitration, or through trade contracts are made between ASEAN entrepreneurs.

Not only the governments of ASEAN countries are involved in legal cooperation, even judges (especially the High Judge and the Chief Justices) can play a role. Through the decision of the judge on a case containing a foreign element (particularly among the ASEAN countries) can form a new legal opinion. It will be led to the level of ASEAN legal cooperation, if the decision can be agreed upon by the ASEAN countries to the decision that taken by the court in one of the ASEAN country. One important thing is not harming the national interests of ASEAN countries. In fact it should be 
legal cooperation with the court's decision is done with the intention of interests (long-term) of ASEAN countries in resolving legal disputes exist between them.

Legal cooperation through the arbitration is also possible to occur since entrepreneurs are more likely to choose arbitration as a means of solving the dispute, so that the presence of these tendencies will grow a new decision in the dispute settlement. With the arbitral award of one of the arbitration in ASEAN countries, it is expected to apply and be implemented in other ASEAN countries on a reciprocal basis. In this regard it should be noted that the agency and the rules of arbitration in ASEAN countries need to be developed in a way that can generate confidence in entrepreneurs and foreign community, particularly the ASEAN entrepreneurs to use arbitration as a means to resolve disputes. Therefore, in drafting legislation on arbitration and fostering arbitration agencies in ASEAN countries, it needs to be cultivated possibility of legal cooperation, for example by incorporating the regulations of the Asian African Legal Consultative Committee Arbitration Centre in Kuala Lumpur, Malaysia whose jurisdiction also includes the ASEAN countries entirely.

Other track to hold legal harmonization is through various forms of international contracts. Therein lies the role of the ASEAN entrepreneurs (which is now incorporated in the ASEAN Chamber of Commerce Organization) to conduct or arrange contracts with terms and conditions that are not too different from the contracts that can be approved by the other ASEAN entrepreneurs. With the standard of the ASEAN contract, it is expected to create a similar form and format, so that the differences can be avoided and the traffic and the volume of trade between the ASEAN entrepreneurs to one another can take place more smoothly.

Through the above description, it appears that in the case of legal cooperation are still in many ways to make it happen, so that legal cooperation is not just a matter that must be considered by the ASEAN countries, but now it has become a problem and it requires the participation of all legal circles of ASEAN countries, including the community. Meanwhile, Komar Kantaatmadja (1985) believes that legal cooperation is an attempt constructive approach, in creating a common ground towards regionalization among ASEAN countries. Therefore, in its implementation, there needs to be a pattern of behavior that is agreed upon. Then the pattern was formulated and laid out or pulled into the rules of the instructions for solving problems that may arise among the ASEAN countries.

ASEAN regionalization cannot run fast like that what happened in European countries through the European Economic Community (EEC). This is because the EEC held a regionalization approach by conducting a long and in-depth research on the behavior, condition, socio-economic and cultural as well as the legal system of each member. After learning the fundamental problem, then later formed a sort of working committee tasked to formulate the general provisions concerning the implementation and regulation mechanisms in the legal cooperation. The final results of the working committee, then approved or confirmed by the European Parliament, where the provisions of the regional law is a principle which applies to all EEC countries. Among the ASEAN countries, the stages as practiced by the EEC, including the creation of a sort of working committee in the European Parliament, has yet to be formed and apparently not yet heading in that direction. This is indeed one of the weaknesses in terms of the scope of ASEAN cooperation in legal cooperation.

Despite the fact that the proposal to establish a sort of commission exists already, Teuku Mohammad Radhie (1987) believes that in order to make a cooperation in ASEAN law, it needs to be established Law Commission of ASEAN. Law Commission of ASEAN's task is to determine which areas are to be covered by the organs of legal cooperation and exchange the study, research, assessments of ASEAN's legal system, as well as the thinking areas of law that needs to be established at the regional level. Means to perform legal cooperation ASEAN is now limited to the meeting of Heads of Government of ASEAN, through the forum of the meeting of the Minister of Justice and Attorney General of ASEAN, and other similar facilities. This is an approach that can be used as a way towards legal harmonization of ASEAN. 
However, in some ways, the approach done by government to government is often difficult to find and formulate the principles of law common to all parties. Among the ASEAN countries, several sectors have a very different perception of legal cooperation. In fact, there is an assumption of Budiono Kusumohamidjojo (1986), to the problem when it is seen from the results so far, "Efforts to develop cooperation in the legal field did not show impressive results in the past ten years".

That is why that Kantaatmadja Komar (1985) said that the ASEAN legal regionalization approach may only be tackled gradually, by bringing together legal cooperation (material) that are not too sensitive (sensitive) but it is the common interest of ASEAN countries. Therefore, the general principle of the development of legal cooperation ASEAN region is an effort of alignment of the various national interests of the countries in a particular region, by way of joint development of legal principles that are similar and same in order to achieve a common ground, which is a legal cooperation more efficient and effective. Efforts need to be explored within the framework of this cooperation are included: 1) An approach such as the development of adequate knowledge of the respective national legal system of the countries of this region. 2) Research to explore a wide range of common interests, followed by identifying the priority pattern in those aspects that need to be addressed and developed mutually. 3) Holding pattern agreement on the handling of regional problems in a more integrated and focused. 4) Unification principles of law governing the mutual interests and needs.

\section{CONCLUSIONS}

As mentioned above, showing the presence of similarity step in realizing the ASEAN legal cooperation. It is expected to gradually reduce the obstacles or barriers, which have always been the main obstacle, are the legal system. Nevertheless, the prospect of legal cooperation ASEAN itself will depend on the political will of the respective governments of ASEAN countries. The political will which presumably will play a greater role in the realization of legal cooperation, which has tended to a common goal of ASEAN countries

\section{REFERENCES}

David, R. (1990). The Internatinal Unification of Private Law. International Enciclopedia of Comparative Law. Volume II, Chapter 5. Tuebingen.

Nugroho, F. Y. (1986). Pertemuan Menkeh dengan Jaksa Agung ASEAN untuk Harmonisasi Hukum. Kompas.

Hartono, S. (1983). Aspek-aspek kerjasama ASEAN di Bidang Hukum. Seminar Harmonisasi Hukum di Negara-negara ASEAN. BPHN-Departemen Kehakiman RI. Komite Nasional ALA dan FH-USU Medan.

Kusumohamidjojo, B. (1986). ASEAN: Di Sepuluh Tahun Deklarasi Bali. Kompas.

Kantaatmadja, K. (1985). Regionalisasi Hukum pada negara-negara ASEAN. Badan Penelitian dan Pengembangan (Litbang), Departemen Luar Negeri RI. Bandung.

Kantaatmadja, K. (1985). Sistem Pendidikan dan Perkembangan Hukum Indonesia dalam menunjang Harmonisasi Hukum ASEAN. Pra Generasi Muda Hukum Indonesia, Jakarta. 
Radhie, T. M. (1983). Beberapa Pemikiran Kerjasama dibidang Hukum Antara Negara-negara ASEAN. Direktorat Jenderal Sekretariat Nasional ASEAN. Departement Luar Negeri RI. Jakarta.

Radhie, T. M. (1986). ASEAN Legal Cooperation. ASEAN Law Association (ALA). Publication of ALA Secretariat, Jakarta.

Radhie, T. M. (1987). Beberapa Pemikiran Tentang Harmonisasi Hukum di Wilayah ASEAN dan Dampaknya terhadap Pembangunan Hukum Nasional. Pidato Dies Natalis ke-30 Fakultas Hukum USU. Medan.

Radhie, T. M. (1988). Beberapa Pemikiran Kerjasama Hukum di Wilayah ASEAN dan Prospeknya di Masa Depan. Indonesia Student Association for International Studies (ISAFIS). Jakarta. 